\title{
Autosomal Recessive Congenital Ichthyosis 2
}

National Cancer Institute

\section{Source}

National Cancer Institute. Autosomal Recessive Congenital Ichthyosis 2. NCI Thesaurus. Code C132827.

An autosomal recessive condition caused by mutation(s) in the ALOX12B gene, encoding arachidonate 12-lipoxyg enase, 12R-type. It is characterized by dry, thickened, scaly skin. 